\title{
Regional Monitoring for Disease Prediction and Optimization of Plant Protection Measures: The IPM Wheat Model
}

Cereals and processed foods derived from them are the principal source of nutrition in many parts of the world. In 1997, wheat (Triticum aestivum L.) was grown on about 239 million hectares, $8 \%$ of which were in western Europe, $16 \%$ in North America, $4 \%$ in eastern Europe, $11 \%$ in the Russian federation countries, and $38 \%$ in Asia. That year, the world wheat production was 600 million $t$. In 1997, the wheat yield of western Europe was 7.1 to $7.6 \mathrm{t} / \mathrm{ha}$, or about twice the yield achieved in the United States (2.7 t/ha) and 3.2 times the yield in the Russian federation (1.7 t/ha) (2). These high yields in western Europe are the result of intensified methods of arable farming and plant cultivation, including minimization of losses through use of plant protection products.

Increasing intensity of wheat cultivation has been achieved through shorter rotations, high plant populations, and multiple nitrogen applications. These agronomic practices result in substantial grain yields but also increased pressure from diseases. Pathogens that have become economically important are Septoria tritici Roberge in Desmaz., Stagonospora (syn. Septoria) nodorum Berk., Drechslera tritici-repentis (Died.) Shoemaker, Puccinia recondita Roberge ex Desmaz., Puccinia striiformis Westend., Pseudocercosporella herpotrichoides (Fron) Deighton, and Erysiphe graminis DC. f. sp. tritici Em. Marchal. Control of the diseases caused by these pathogens has a high priority in minimizing yield losses. Therefore, the use of fungicides in wheat is concentrated mainly in western Europe, where $85 \%$ of the worldwide fungicide use is applied on wheat at an annual cost of US $\$ 1.589$ billion (1998).

Dr. Verreet's address is: Department of Phytopathology, University of Kiel, Germany

E-mail: javerreet@phytomed.uni-kiel.de

Publication no. D-2000-0605-01F

(C) 2000 The American Phytopathological Society
The occurrence of individual pathogens and the economic significance of the diseases they cause can vary substantially in different climatic zones and production systems. Epidemiological development of pathogens is strongly dependent on the weather. Together with differences among cultural practices, this leads to differences in the onset, course, and severity of the disease complex from one year to the next.
Decisions on the need to apply fungicide, application timing, and choice of active ingredient have hitherto been guided largely by experience. Such decisions, however, often cannot be regarded as optimal when economic and ecological aspects are also taken into account.

Spray decisions are often made according to a "precautionary" principle based on the crop's growth stage. It cannot be as-

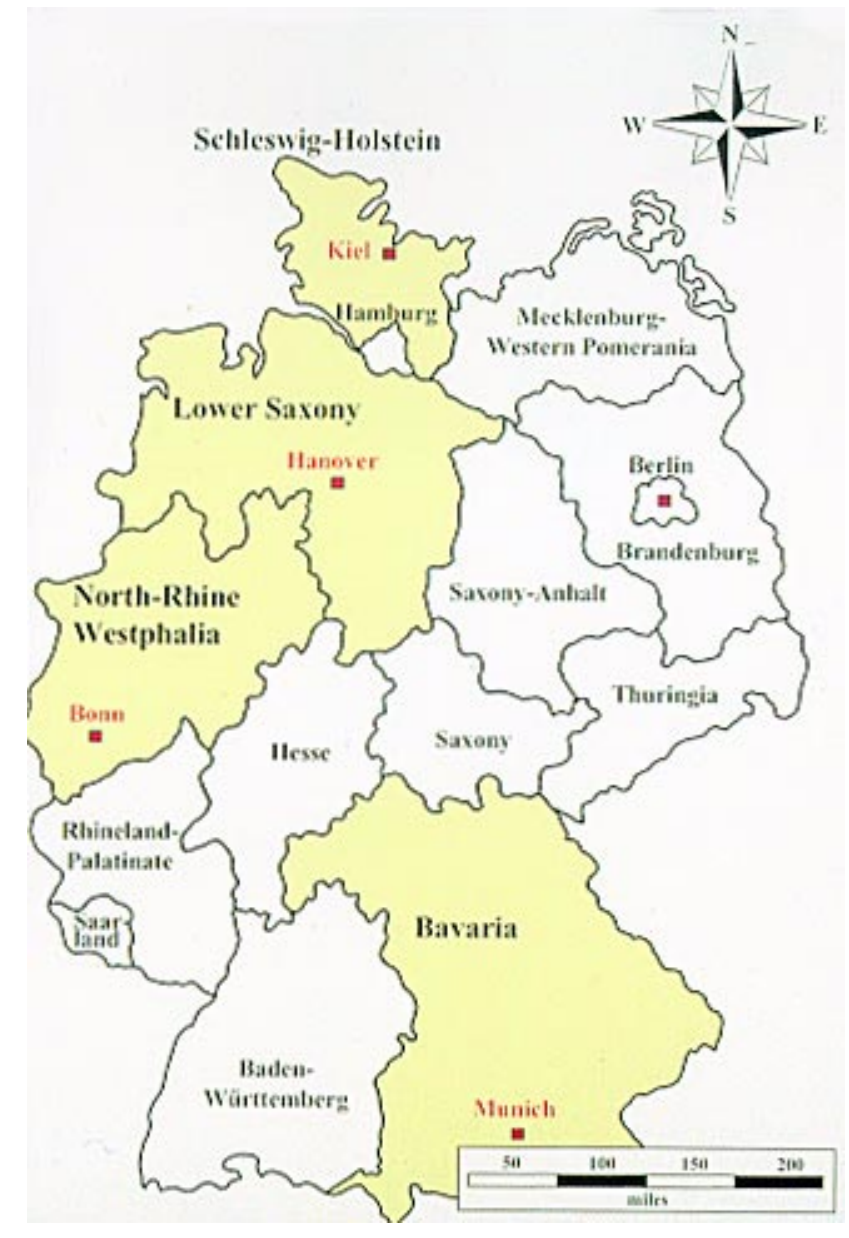

Fig. 1. German states where the IPS wheat model has been introduced (Bavaria, Schleswig-Holstein). Introduction scheduled in 1999: Lower Saxony, North-Rhine Westphalia). 
sumed, however, that this system will always control the pathogen population at the most sensitive stage of its population dynamics. From the epidemiological point of view, growth stage-oriented treatments are randomly timed and therefore may be only partially successful, and the possibility of economically and ecologically unjustifiable applications cannot be ruled out.

In a multiyear cooperation among the plant protection services of the German states Bavaria and Schleswig-Holstein and the Universities of Munich and Kiel (Fig. 1 ), an integrated plant protection system (IPM wheat model) was developed for the most important fungal wheat diseases. Epidemiological and yield studies were carried out within the framework of annual regional monitoring programs. Using wheat as a model, the aim of the project is to show how fungicide applications can be reduced to the absolute minimum necessary for pathogen control.

\section{Precise Diagnosis: A Key to Optimal Disease Control}

A key element of the IPM wheat model is that the applicator of fungicides (farmers, trials managers, and advisers) must be capable of accurately diagnosing the various wheat pathogens in individual crop stands (Fig. 2). At the same time, the actual pathogen population densities should be assessed. Visual diagnosis based solely on browning or necrosis characterizing disease intensity is an unsatisfactory basis for fungicide application decisions because it is prone to false interpretation (Fig. 3). Accurate identification of pathogens and assessment of population densities offer users of the IPM model the potential for precisely timed fungicide applications and an informed choice of the fungicide best for each pathogen. Within this framework, an appliance has been developed for field diagnosis that facilitates qualitative diagnosis of wheat pathogens (Fig. 4).

\section{Defining Disease Control Thresholds}

For optimizing plant protection treatments, an important basic principle is development of pathogen-specific control thresholds. Individual disease control thresholds for each pathogen must be determined over many years of research. Threshold values establish those popula- tion densities which, when exceeded, lead to short- or long-term commercial loss. This threshold defines the optimal time for applying fungicide (Fig. 5).

The effectiveness of targeted fungicide treatments depends on the flexibility and the adaptability of pathogen-specific threshold values, as well as on cultural and environmental influences. Specific epidemiological control thresholds for the most important pathogens of wheat (Septoria tritici $\quad[10,12,13,18,20], \quad$ Stagonospora nodorum [17-20], Drechslera tritici-repentis [18,21,22], Puccinia striiformis [10,18], Pseudocercosporella herpotrichoides $[1,7,9]$, and Erysiphe graminis f. sp. tritici $[1,7,8,11,18])$ have been developed through field studies. The efficacy of these threshold values was evaluated in the context of crop rotations and environmental conditions over several years in different regions of Germany $(10,17,18)$. The initial application and the choice of fungicide are defined when the threshold for one or several pathogens is reached or exceeded. Effects of a spray against the target organisms, and side effects against the entire pathogen spectrum, in conjunction with further monitoring and diagnosis, inform

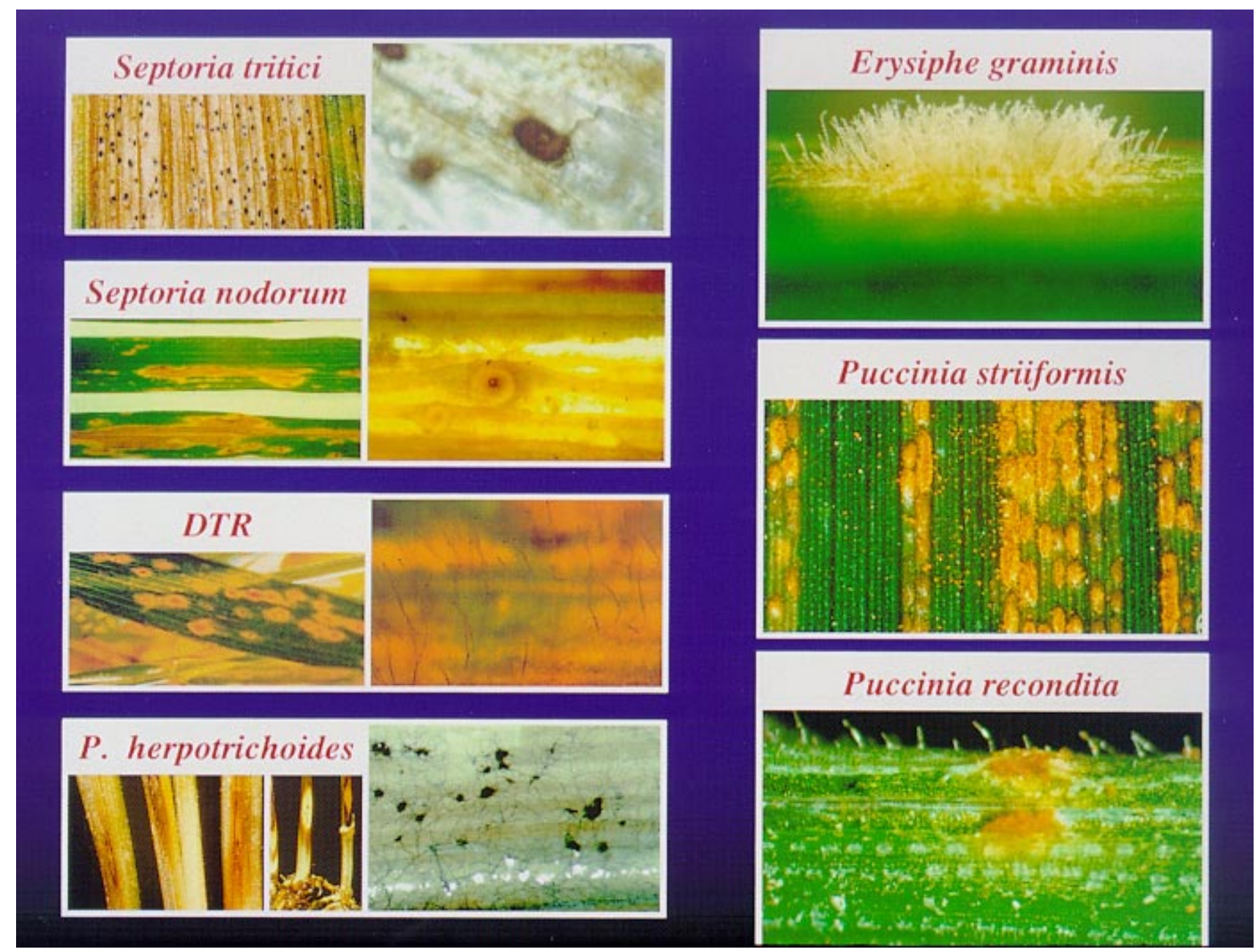

Fig. 2. Symptoms of diseases caused by wheat pathogens (clockwise from upper right): Erysiphe graminis, powdery mildew; Puccinia striiformis, yellow rust; Puccinia recondita, brown rust; Pseudocercosporella herpotrichoides, eye spot; DTR-Drechslera tritici-repentis, tan spot; Stagonospora - syn. Septoria nodorum, glume blotch; Septoria tritici, leaf blotch. 
decision-makers on the necessity of follow-up sprays. Fungicide sprays are timed to coincide with the transition from primary to secondary inoculum and from primary to secondary infection, especially of the upper, yield-essential plant organs.
To analyze a pathogen-specific threshold value, an example will be given for Erysiphe graminis (Fig. 5). Population dynamics of powdery mildew were monitored macroscopically by counting pathogen-specific fungal structures (mildew pustules). At

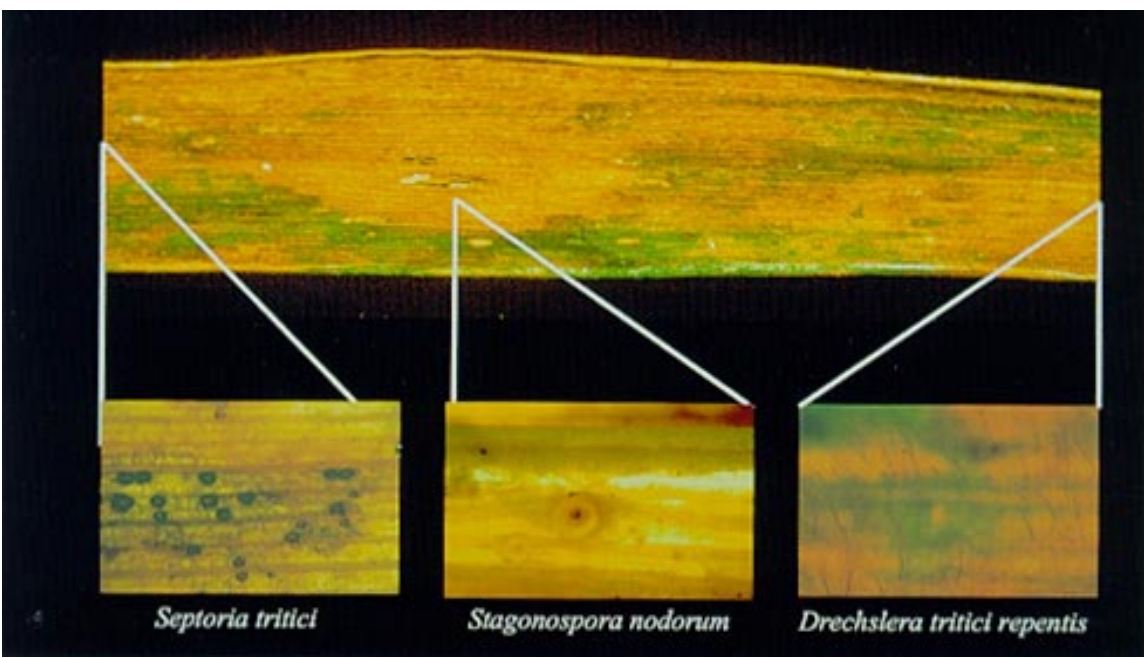

Fig. 3. Macroscopic (nonspecific) and microscopic (specific) evaluation of the causes of the disease complex of wheat.

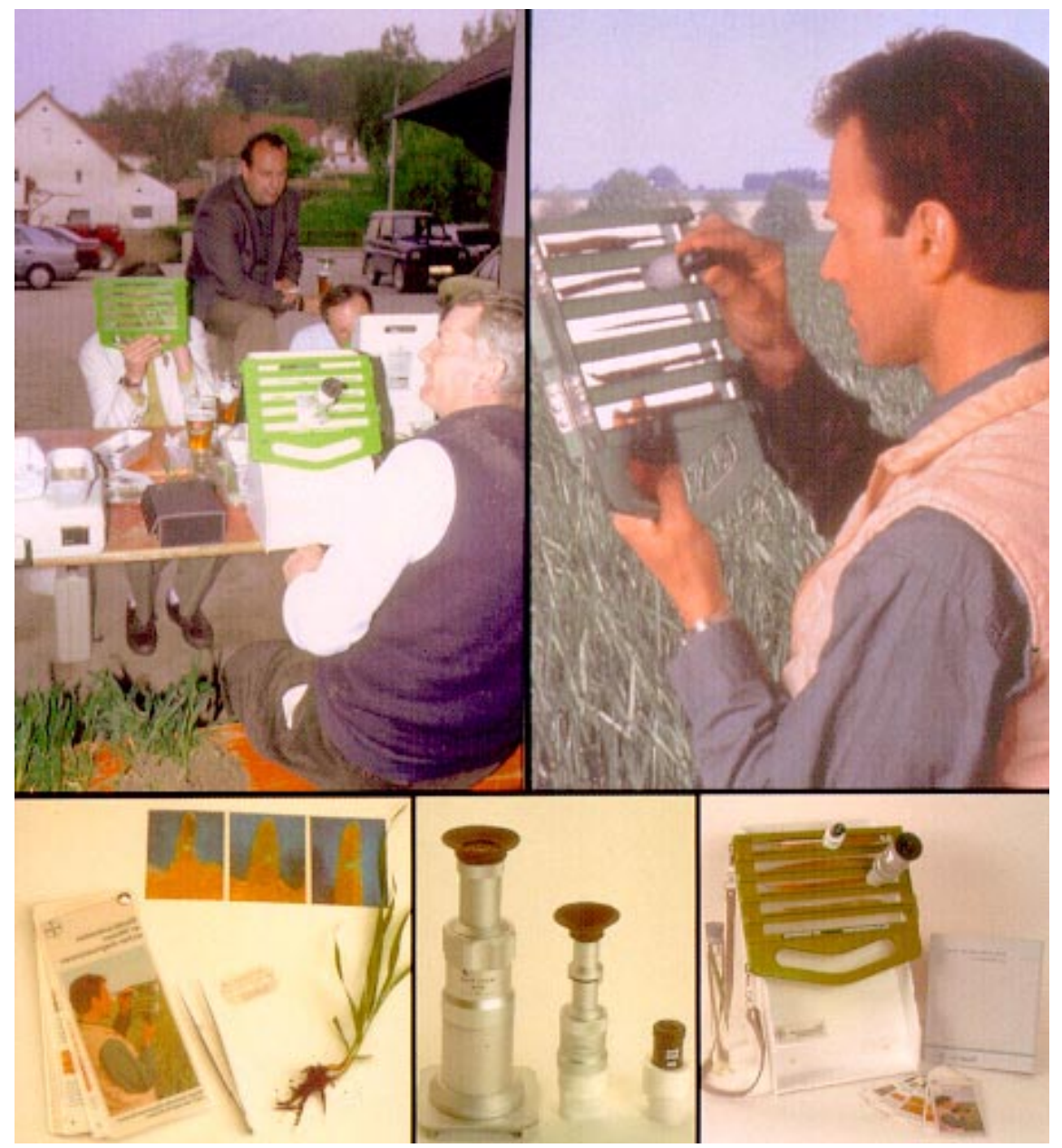

Fig. 4. The Bayer Cereals Diagnostic System (19) offers an exact identification of fungal structures (e.g., pycnidia or conidia) in nonspecific necroses. The system consists of two hinged transparent plastic plates with a rail mounting for a monocular lens system $(\times 30$ to $\times 100)$, between which are placed moistened leaves with necrotic lesions which are then inspected with the aid of natural light (in the field) or artificial light sources (light box, laboratory). weekly intervals (GS 30 to GS 75, threshold-based treatment period), disease incidence (DI) (percentage of infected plants or leaves per leaf position) was calculated from a sample of 30 plants. The first threshold of $70 \%$ DI is reached if mildew pustules have been diagnosed on 21 of the 30 plants in the sample. Under favorable weather conditions and cultural practices (e.g., high doses of nitrogen fertilizer, susceptible variety), a renewed buildup of the powdery mildew population can take place 3 weeks after the first threshold-oriented treatment. The second threshold of $70 \%$ DI is reached if, on the topmost green leaves (F-2 and F-1 = third and second leaf from top, respectively; $\mathrm{F}=$ flag leaf), an average of $\geq 21$ of 30 plants show at least one mildew pustule.

Fungicide strategy. Fungicides can be chosen according to the key pathogen(s) present in the crop. The active ingredient used depends on the target pathogen established in the crop during the vegetative period and its threshold values, together with the growth stage (GS) of the wheat plant at that time (Fig. 6). The threshold values allow the same efficacy from the application of reduced amounts of fungicide as with the recommended amounts in standard practice. Should the first threshold treatment be required before GS 39, fungicide is applied with reduced amount of active ingredient $(50 \%)$. A repeat treatment applied later in the vegetation period, which may be required if the threshold is exceeded again (assuming a 4-week period of fungicide effectiveness and diseaseconducive weather), is carried out with a reduced amount of active ingredient $(50 \%)$.

If the threshold is exceeded for the first time between growth stages GS 41 and GS 59 , one can choose applications of an increased amount of active ingredient to provide long-term disease control and to minimize the number of subsequent treatments, thus covering a plant development phase extending until grain ripening. Should the threshold value be exceeded during this phase, a final threshold treatment is applied. The choice of a higher dose of active ingredient in this period is intended to avoid the danger of conducive weather leading to a renewed increase of disease and subsequent crop damage after GS 69-a phase when applications of fungicides are generally not labeled. With advanced development of wheat (from GS 61 ), the amount of fungicide used is reduced to a minimum that still allows for optimal disease control. Should the threshold value be exceeded for the first time during growth stages GS 61 to GS 69, a reduced spray dose $(50 \%)$ is applied without a subsequent second treatment. The fungicide strategy here is, once again, based on epidemiological information, which documents that where disease outbreaks occur late in crop development, they usually only result in medium damage 
levels, even under the most conducive conditions, and can be optimally controlled through reduced-dose fungicide application. The control of wheat pathogens with reduced amounts of fungicide will, however, only be successful where the fungicide is applied according to epidemiological criteria from defined threshold values. The use of fungicide should be avoided where the threshold value is not exceeded during the entire vegetative period.

\section{Regional Monitoring in Schleswig-Holstein}

Pathogen population dynamics and disease incidence in wheat crops were studied regionally from 1993 to 1998 at an average of 11 trial sites in Schleswig-Holstein, all of which were equipped with weather stations (Fig. 7). Sampling was done at weekly intervals, and all pathogens appearing throughout the growing season on all plant organs $(\mathrm{F}-8=$ ninth leaf from top to $\mathrm{F}=$ flag leaf) were recorded qualitatively (according to fungus structure) and quantitatively (fungal population density, disease severity). Data on pathogens exceeding threshold values were collated by students with stereoscopes in the laboratory, sent weekly to the state plant protection advisory service, and made available to all advisory institutions and specialists (farmers and official, industrial, and private advisers) (Fig. 8). Plant sampling, crop management, and harvesting were carried out by the Schleswig-Holstein federal plant protection service.

The epidemiological effects of the threshold treatment were compared with a fungicide-free control (Fig. 7) and with a "healthy-standard treatment" (treated three to four times according to growth stage).

Cultural practices. With a crop area of 175,747 ha, winter wheat in SchleswigHolstein represents $57.0 \%$ of the state's total grain area. On average, the yield in 1997 was $9.07 \mathrm{t} / \mathrm{ha}$, resulting in a total harvest of 1.29 million $t$. On the interregional monitoring sites over the years 1993 to 1998, winter oilseed rape preceded wheat in the rotation in 60 to $70 \%$ of cases, and winter wheat monoculture was the preceding crop in about $30 \%$ of the cases. Other crops (sugar beet, maize, oats, or summer wheat) preceded winter wheat in only $1 \%$ of the cases. The most commonly used soil cultivation procedure was plowing, followed by sowing after use of a rotary harrow; this practice was used in $75 \%$ of cases on average. The remainder of the monitoring sites were drilled in no-till sowing systems. On two-thirds of the areas, the level of mineral fertilizer application in the trial fields averaged 170 to 230 $\mathrm{kg} \mathrm{N} / \mathrm{ha}$; in other cases, the fertilizer application level reached 230 to $260 \mathrm{~kg} \mathrm{~N} / \mathrm{ha}$.

\section{Overview of Disease Severity from Wheat Pathogens}

Six of 11 monitoring sites were highlighted according to site, year, specific pathogen, and disease data (Fig. 9). The leaf blotch disease caused by Septoria tritici dominated the disease situation across the regions and years and represents the major damaging pathogen. In 1996, periodically unfavorable weather conditions meant that $S$. tritici outbreaks were substantially reduced.

Powdery mildew, in contrast, appeared at increased levels only at a few locations and years. The pathogen, however, dominated the disease complex in 1996. The disease appeared mostly in the eastern areas, while not once appearing on the west coast. This is due primarily to the topographical and climatic conditions on the west coast. There, the natural barrier of the North Sea, together with the prevailing northwest winds, obstruct the establishment of the pathogen near the coast.

Yellow rust, outbreaks of which are highly dependent on the susceptible cultivar Kanzler, reached high levels on the west coast only in 1993. Tan spot, caused by Drechslera tritici-repentis, could be identified only in 1997 and 1998 at all locations, in 1998 in some cases with substantial disease progression. Eye spot (Pseudocercosporella herpotrichoides) and brown rust appeared only in isolated outbreaks or not at all. A low level of glume blotch, caused by Stagonospora nodorum, was limited to the eastern regions of Schleswig-Holstein.

It is clear from population-dynamic studies that the reliance of wheat patho-

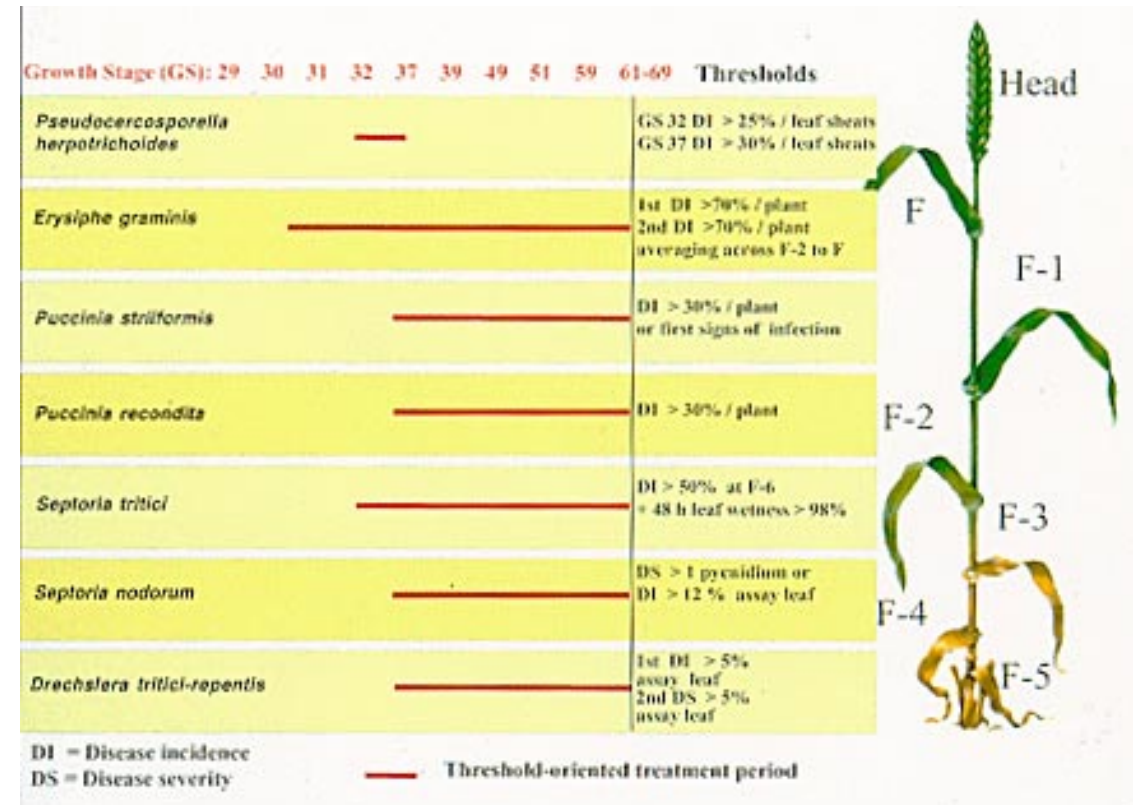

Fig. 5. Control thresholds of the IPM wheat model as used in Germany.

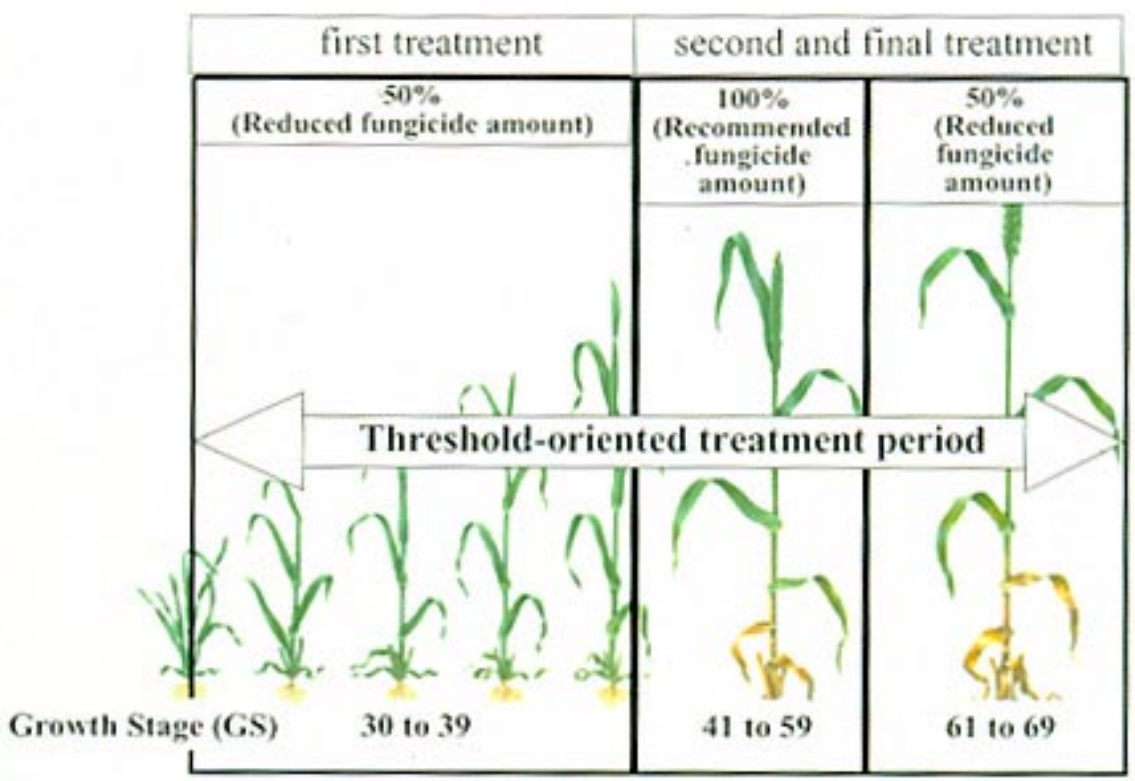

Fig. 6. Fungicide strategy of the IPM wheat model. 
gens on weather leads to changing disease intensity patterns from year to year with notably different onset and course of epidemic development. Optimal control of pathogen complexes is, therefore, only achievable through a fungicide program tailored exclusively to the local disease situation. Because of this, plant production and weather influences must be analyzed in detail so that the information can be integrated into the development of threshold values.

\section{Development of a Prognosis Against Septoria tritici}

While tested control thresholds are available for Stagonospora nodorum, Drechslera tritici-repentis, Puccinia recondita, Puccinia striiformis, Pseudocercosporella herpotrichoides, and Erysiphe graminis f. sp. tritici, it has been possible only recently to produce an epidemiological and weather-based control concept for Septoria tritici. $S$. tritici is the most damaging pathogen in the wheat growing areas of Schleswig-Holstein. Under the topographical and climatic conditions in this state, the pathogen appears with high population intensity irrespective of region and location (Fig. 9). Early and continual development of the pathogen is encouraged by prevailing cultural and climatic conditions (high precipitation, little continuous frost in winter) as well as agritechnical demands (early sowing with wheat crops close together in the rotation). Analysis of population and damage dynamics, together with weather criteria (precipitation, relative humidity, and leaf wetness requirement for infection), have led to development of a functional control strategy that provides a high degree of pathogen control with minimal fungicide application.

The typical infection course, with sudden outbreaks (15) of symptoms reappearing in the crop from June onward, can be traced back to precipitation intensity in May. The asexual, epidemiologically important development cycle of the pathogen is very strongly dependent on moisture and temperature. According to Gheorghies (3), germination takes place from 2 to $37^{\circ} \mathrm{C}$. The optimal germination temperature is recognized by Shipton et al. (16) as being in the range of 22 to $24^{\circ} \mathrm{C}$. Infection is encouraged at a temperature between 16 and $21^{\circ} \mathrm{C}$. Around $7^{\circ} \mathrm{C}$, infection is inhibited (6). Penetration of the host tissues is completed after $24 \mathrm{~h}$ and can take place directly over the cuticle or through stomata (5). Spore release is twice as rapid at $100 \%$ relative humidity as at $98 \%$; and at $100 \%$ relative humidity, 11 to 23 times the number of spores are produced as at $86 \%$ relative humidity (RH) (4). Vertical and horizontal spread of the pathogen takes place through the kinetic energy of striking raindrops. Dispersal and infection take place when within 3 days total precipitation exceeds $10 \mathrm{~mm}$, or over 2 days total precipitation exceeds $5 \mathrm{~mm}$, and there exists a continuous 3-day-long leaf wetness period $(12,14)$. Based on an epidemiological field study of the pathogen development cycle, the shortest latent period under optimal conditions was 28 days. From detailed climate data and population-dynamic studies on different leaf positions (F-3 = fourth leaf from top to $F=$ flag leaf) (Fig. $10)$, it is clear that the criteria for a successful infection (leaf wetness period of

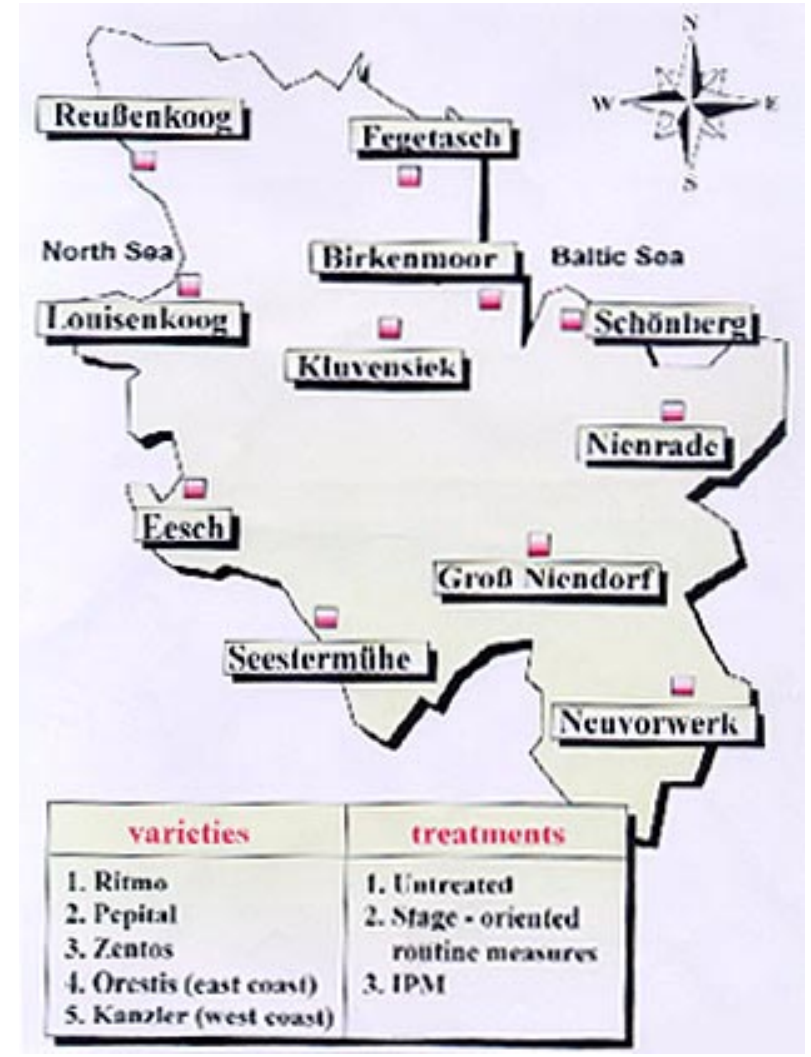

Fig. 7. Trial facilities for regional disease prediction monitoring in Schleswig-Holstein, including trial locations, varieties, and trial variations from 1993 to 1998. At 11 trial sites, wheat pathogens were qualitatively and quantitatively identified by stereoscope on all leaves from the earliest to the latest phase of plant development (GS 30 to GS 75, 12 sampling dates). The trial comprises three varieties with different susceptibility grades, in randomized trials with three treatments and four replications. Treatment $1=$ untreated control; treatment 2 = three to four fungicide applications according to growth stage; treatment $3=$ IPM wheat model, control thresholds, and fungicide strategy.

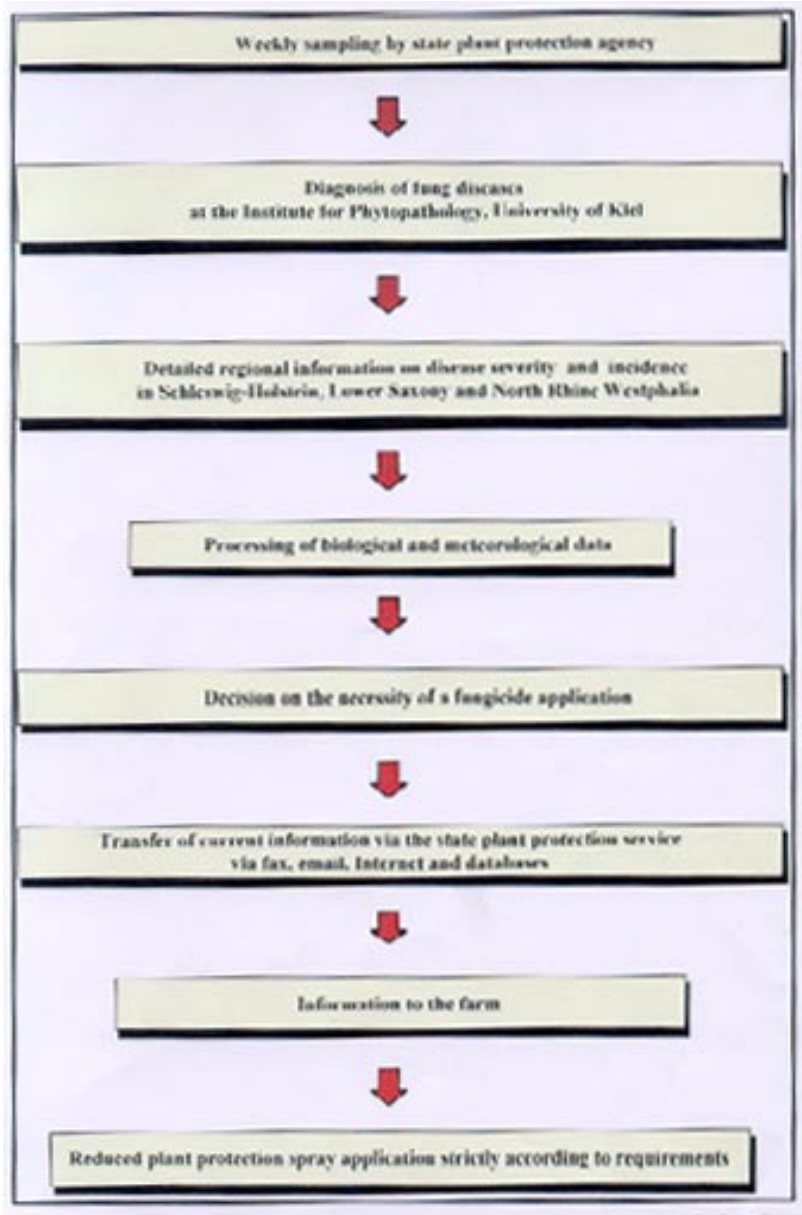

Fig. 8. Logistics of regional disease severity recording in Schleswig-Holstein. Weekly sampling (beginning April to end of July) was carried out regionally every Monday by the official service, diagnoses were made at the Institute of Phytopathology, and biological data, with appropriate advice on disease control measures, together with threshold values, were communicated via Internet. 
more than $48 \mathrm{~h}$ and relative humidity content greater than 98\%) were satisfied on 29 May in growth stage GS 37. During the latent period of 4 weeks, a definite population increase was initiated on the upper leaves F-2 to F, the further development of which was not continued because of unsuitable weather conditions (19 June to 17 July), especially on the flag leaf (F). On the other hand, earlier precipitation events (8 May, GS 32; 15 May, GS 33) lacked epidemiological significance because, despite a sufficient level of precipitation for successful infection, the necessary leaf wetness periods were not achieved.

Figure 11 shows the increase in the development of Septoria tritici pycnidia over time on the middle leaf positions $(\mathrm{F}-3=$ fourth and F-2 = third leaf from top) in untreated crops $(n=68)$. The middle position leaves represented the main inoculum source for the contamination of upper, yield-essential leaves ( $\mathrm{F}=$ flag leaf and $\mathrm{F}-1$ $=$ second leaf from top). It is clear that, in conjunction with an infection occurrence, the strongest disease progression resulted within 28 days of the latent period. In the assessment of a crop stand for the presence of Septoria tritici, a distinction must be made between latent and visual infection. A treatment based on visual diagnosis alone, and cued by disease symptoms, leads to only partial success in terms of disease control, in that the causative infection already lies nearly 4 weeks in the past. Consequently, irreversible damage has already occurred. By characterizing the pathogen-specific infection processes, fungicides can be applied during the epidemiologically sensitive phase of the pathogen. Thus, full use can be made of the protective and curative abilities of the active ingredients.

The connection between optimal control of Septoria tritici with regard to infection conditions and the properties of modern fungicides, compared with symptom-oriented treatment, was demonstrated in a case study (Fig. 12). The disease increases were due to two early infection events (16 May, 23 May, sufficient precipitation and leaf wetness period $>48 \mathrm{~h},>98 \% \mathrm{RH}$ ) and characterized by a sufficient inoculum potential (see pycnidial counts on untreated

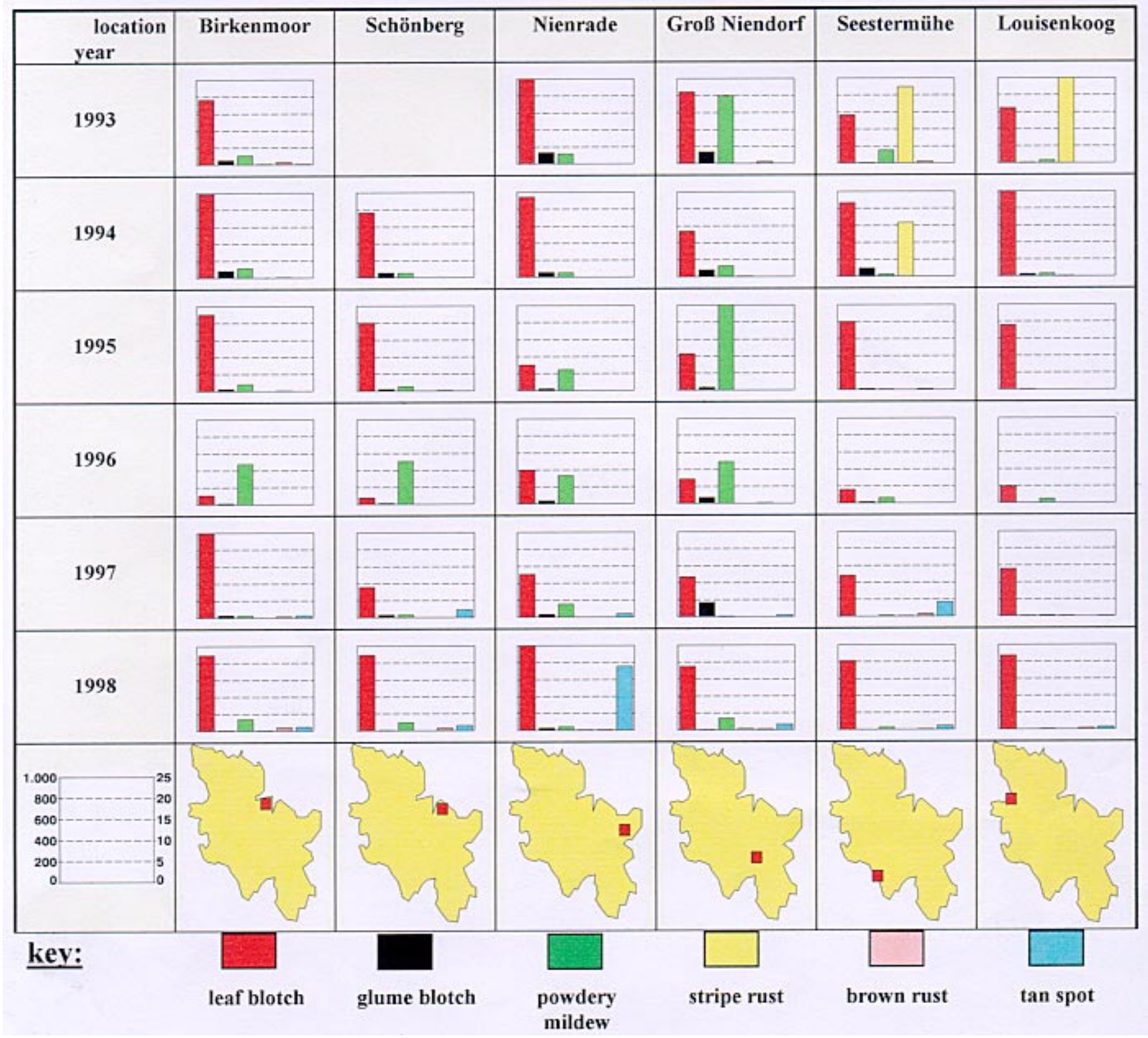

Fig. 9. Regional disease severity on wheat at six sites in Schleswig-Holstein in the untreated control treatment at growth stage GS 75 calculated over the leaf levels F-6 to F in 1993 to 1998. Disease severity caused by Septoria tritici and Stagonospora (syn. Septoria) nodorum is represented as the number of pycnidia per plant (F-6 = seventh leaf from top to $F=$ flag leaf, 0 to 1,000$)$. Powdery mildew (Erysiphe graminis) and rust (Puccinia recondita, $P$. striiformis) disease severity is represented by the percentage of leaf and head surface per plant covered with pustules (F-6 to F, 0 to $25 \%$ ). 
control). After a latent period of 4 weeks in the untreated control, Septoria tritici populations rose continually from 6 June to 18 July. Triggered by the two early infection periods, the first fungicide application was on 18 May. This controlled the latent infection with curative and protective measures. Considering the postinfection effective period for the spray, which is limited to 3 to 4 weeks from the primary fungicide application, a second application on 15 June followed a third infection event (7 to 9 June). Through this double application during the sensitive phase, the disease

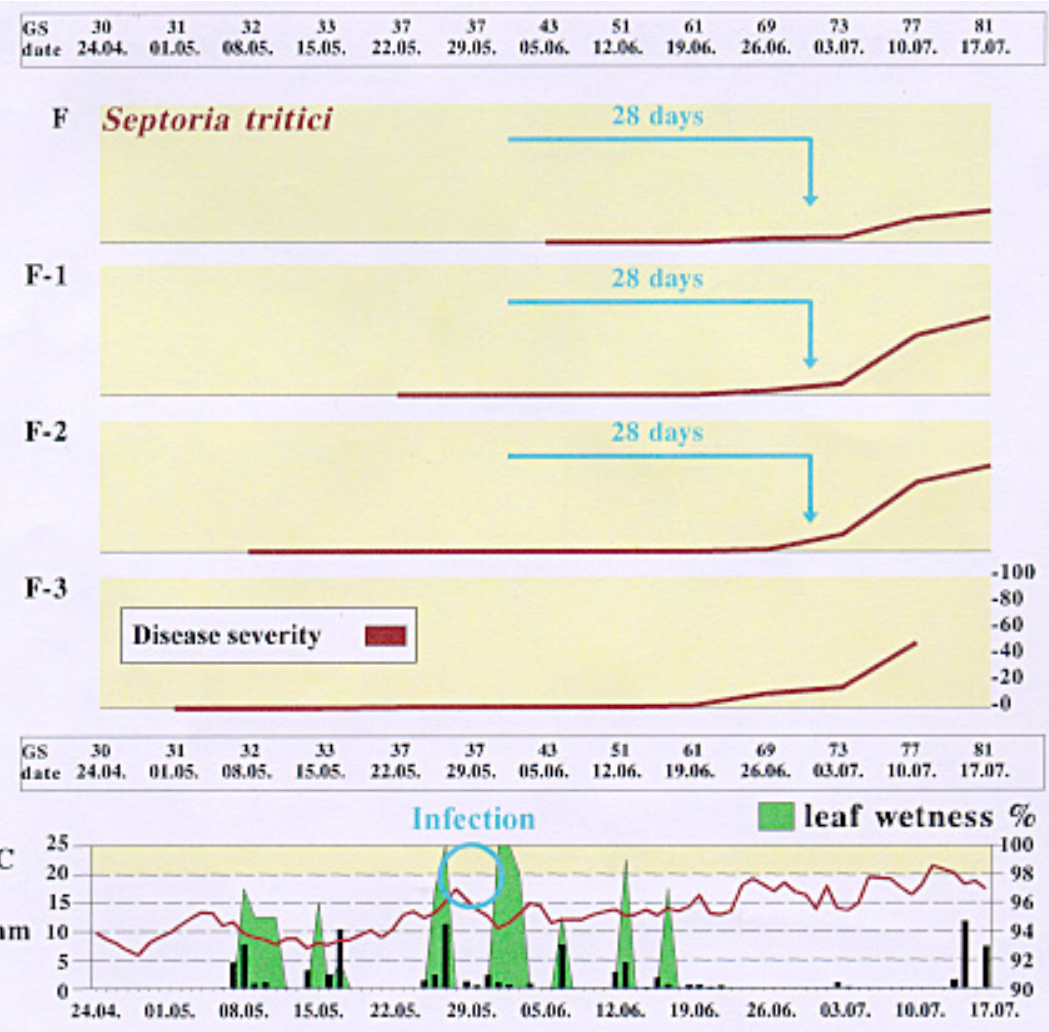

Fig. 10. Dynamics of the latent period (28 days) and disease severity of Septoria tritici in relation to the infection conditions (leaf wetness period of more than $48 \mathrm{~h}$ and relative humidity greater than $98 \%$ ) on the leaf positions $F-3=$ fourth from top to $F=$ flag leaf in the untreated control; variety Pepital, site Klausdorf/Fehmarn, 1995. Disease severity of Septoria tritici = pycnidia count per leaf, sampling period beginning at growth stage GS 30 to GS 81 (24 April to 17 July). Weather data: temperature $\left({ }^{\circ} \mathrm{C}\right)$, precipitation $(\mathrm{mm})$, and leaf wetness $(\%)$.

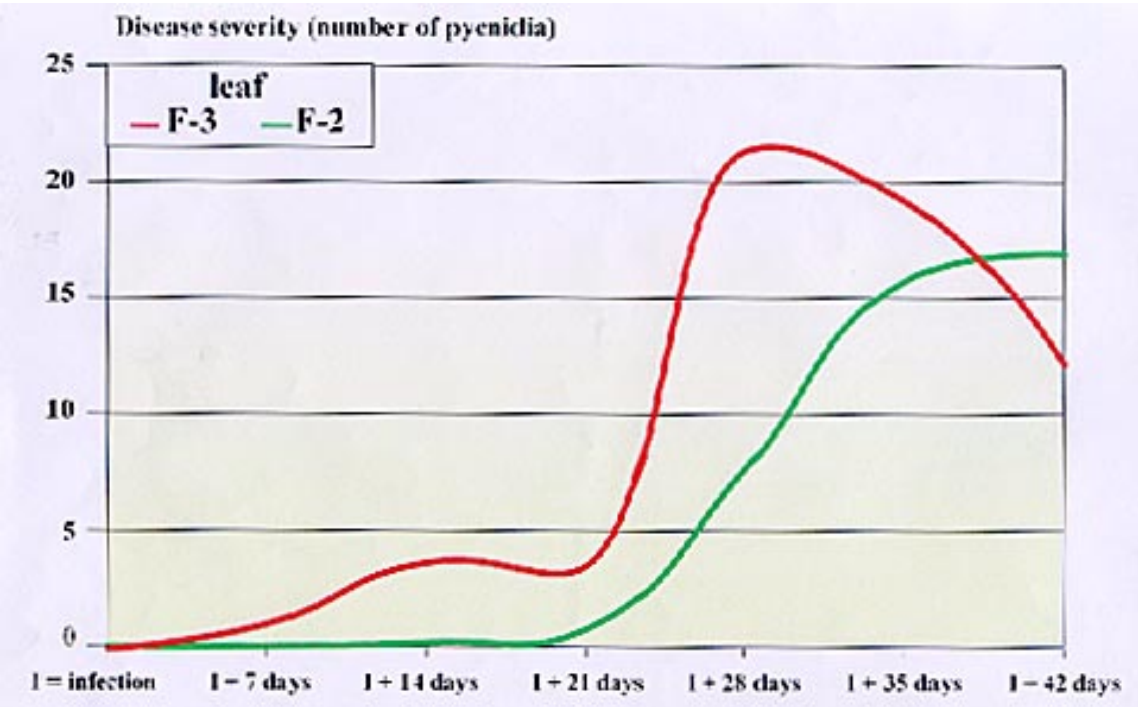

Fig. 11. Pycnidial counts from Septoria tritici following infection (I) of the leaf positions F-3 and F-2 in the untreated control $(n=68)$. course was efficiently controlled with reduced fungicide use.

Until now, there has existed no suitable measuring technology for accurately analyzing and interpreting the epidemiological model for Septoria tritici in connection with essential weather criteria. Along with the measuring technique now available and used in conjunction with the calibration of epidemiological parameters, a SeptoriaTimer has been developed. The SeptoriaTimer (Fig. 13) is placed in the crop at the beginning of the vegetation period (from GS 32). The equipment consists of a sensor for the detection of leaf surface wetness and a datalogger. From the subsequent information, the starting point for Septoria tritici infections is calculated on the basis of a leaf wetness period of more than $48 \mathrm{~h}$ and relative humidity greater than $98 \%$. The result is then shown over an easily read display. After a Septoria warning is given, the initial outbreak must be diagnosed and quantified. If both criteria for infection are fulfilled (warning given by the Septoria-Timer and an initial infection $>50 \%$ disease incidence on the F-6 leaf layer), a fungicide application is required.

\section{Case Studies in Control of Septoria tritici}

A case study of control of the disease using the IPM wheat model will be described through detailed studies of population dynamics. On the Eesch site in 1995, Septoria tritici dominated the disease complex (Fig. 14). At the beginning of sampling (24 April, GS 30), the pathogen was identified on the lowest leaf positions (F-6, F-5) in the untreated control. Through a substantial outbreak around 29 May on the basis of existing pycnidia on F-6 and F-5, the upper leaf positions were inoculated. Within the latent period of 3 to 4 weeks, Septoria moved increasingly onto leaves F3 to $\mathrm{F}$ in the untreated crop and achieved high pycnidial counts.

After the epidemiologically determined infection period (29 May), a fungicide (epoxiconazol plus fenpropimorph) was applied at half (0.5 liter/ha) or full rate (1.0 liter/ha) on 31 May according to the Septoria-Timer. The development of Septoria tritici on the upper, yield-essential leaves (F-1, F) was controlled almost $100 \%$ up to the end of the season with targeted application of either fungicide rate. The yield increases compared with the untreated control-1.64 t/ha (reduced dose) or 1.73 $\mathrm{t} / \mathrm{ha}$ (full dose) -indicate that application of a reduced rate during the epidemiologically sensitive phase of the disease protects the yield potential. A net economical increased yield of US \$201/ha (full dose) and US \$203/ha (reduced dose) resulted.

An overview (Fig. 15) documents the extent of control of Septoria tritici over the Schleswig-Holstein region. It is clear that the pathogen in all years and all locations was controlled effectively through orient- 


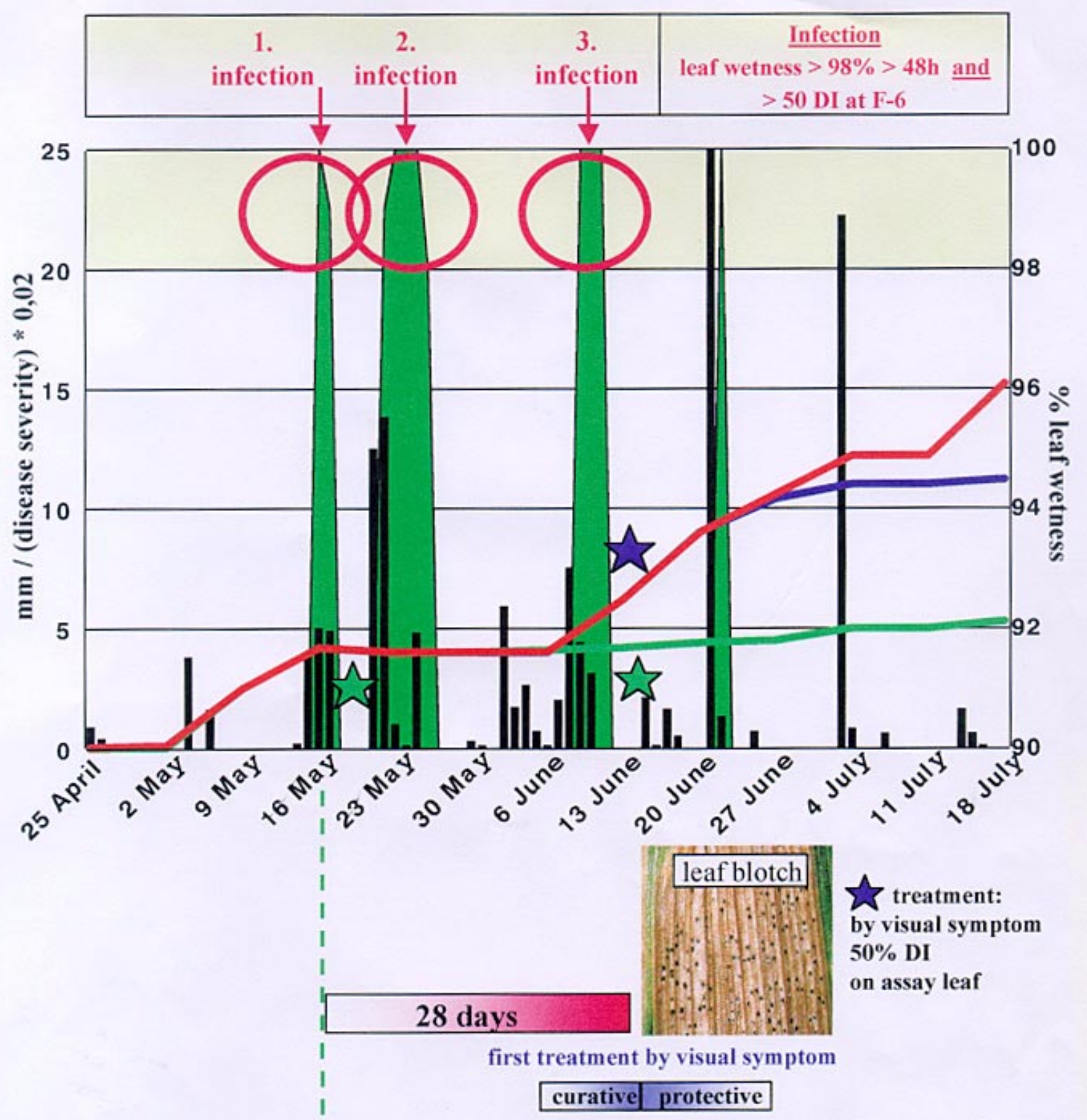


ing the fungicide treatment according to the infection requirements of the pathogen and the decisive weather criteria.

\section{Effects of IPM Wheat Disease Warning Model}

Evaluation of the IPM wheat warning system documented, in nearly all pathogenspecific case studies (information from 118 case studies), optimal control of outbreaks compared with growth stage-based routine treatments. The conventional growth stageoriented fungicide treatments increased yield compared with the untreated control by $1.6 \mathrm{t} / \mathrm{ha}$; this level could not be achieved in all cases through the IPM wheat model (average of $1.3 \mathrm{t} / \mathrm{ha}$ ). Through financial valuation involving calculation of the amount of fungicide applied and the frequency of applications, however, the economic advantages of the IPM wheat disease warning model were apparent. Compared with the untreated control, they resulted in an increase of US \$98/ha, and compared with the growth stage-oriented treatments, an increase of US $\$ 36 / \mathrm{ha}$. The ecological advantages of the IPM wheat warning system compared with fixed fungicide programs are documented through a reduction of the total amount of active ingredient applied by $60 \%$ and of the frequency of application by $43 \%$ (Table 1).

\section{Conclusions}

Progress from development (diagnostic, pathogen-specific threshold value) of the IPM wheat model to broad practical introduction (monitoring through to regional pathogen damage control) has been documented. An almost complete elimination of ineffectual treatments through the removal

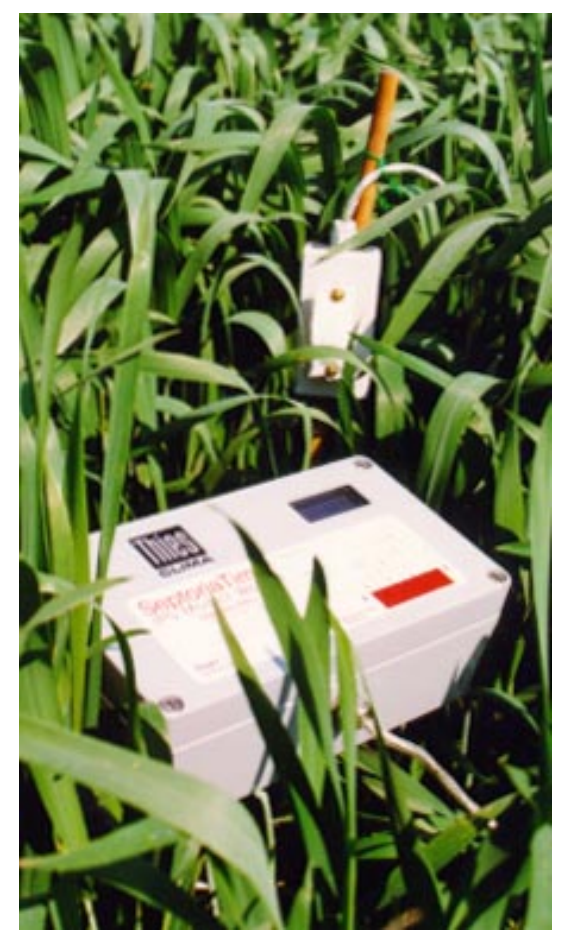

Fig. 13. Septoria-Timer in the crop. of false diagnostic interpretations has occurred through qualitative and quantitative diagnosis of symptoms; this can be regarded as the greatest success stemming from the system's introduction into a broad range of practical wheat cultivation situations. Additionally, application of fungicides can be suited to the location and the varying disease outbreaks and damage dynamics according to the year, and reduced to the absolutely necessary amount in order to achieve optimal yield.

The key to this system is the locally based disease risk assessments, which react appropriately and flexibly to variations in the cultivation system and weather conditions, and thus define optimum fungicide treatments. Through intensive cooperation with the German plant protection services, the optimization of plant protection measures presented here, along with those in Bavaria, has already received broad acceptance within commercial wheat growing in Schleswig-Holstein; indeed, the concept is an accepted part of official advice within Schleswig-Holstein. In 1999, the IPM wheat model was introduced into farms by the plant protection services in the federal states of North Rhine Westphalia and Lower Saxony.

Table 1. Average of 5 years' regional results from 1994 to 1998 (information from 118 case studies) in relation to yield (absolute t/ha, relative \%) economic return (in US $\$ / \mathrm{ha}$ ), and ecological effects (active ingredient $\mathrm{g}$ a.i./ha) for threshold-oriented fungicide treatment (IPM wheat model), stage-oriented routine measures, and untreated control

\begin{tabular}{lccc}
\hline & Untreated & Stage oriented & IPM wheat model \\
\hline Yield (t/ha) & 8.46 & 10.09 & 9.79 \\
Yield (\%) & 100 & 119.3 & 115.7 \\
Monetary surplus (\$/ha) & $\ldots$ & 62.06 & 97.98 \\
Application frequency & $\ldots$ & 3.5 & 2.0 \\
Active ingredient g a.i./ha & $\ldots$ & 1270 & 508 \\
\hline
\end{tabular}
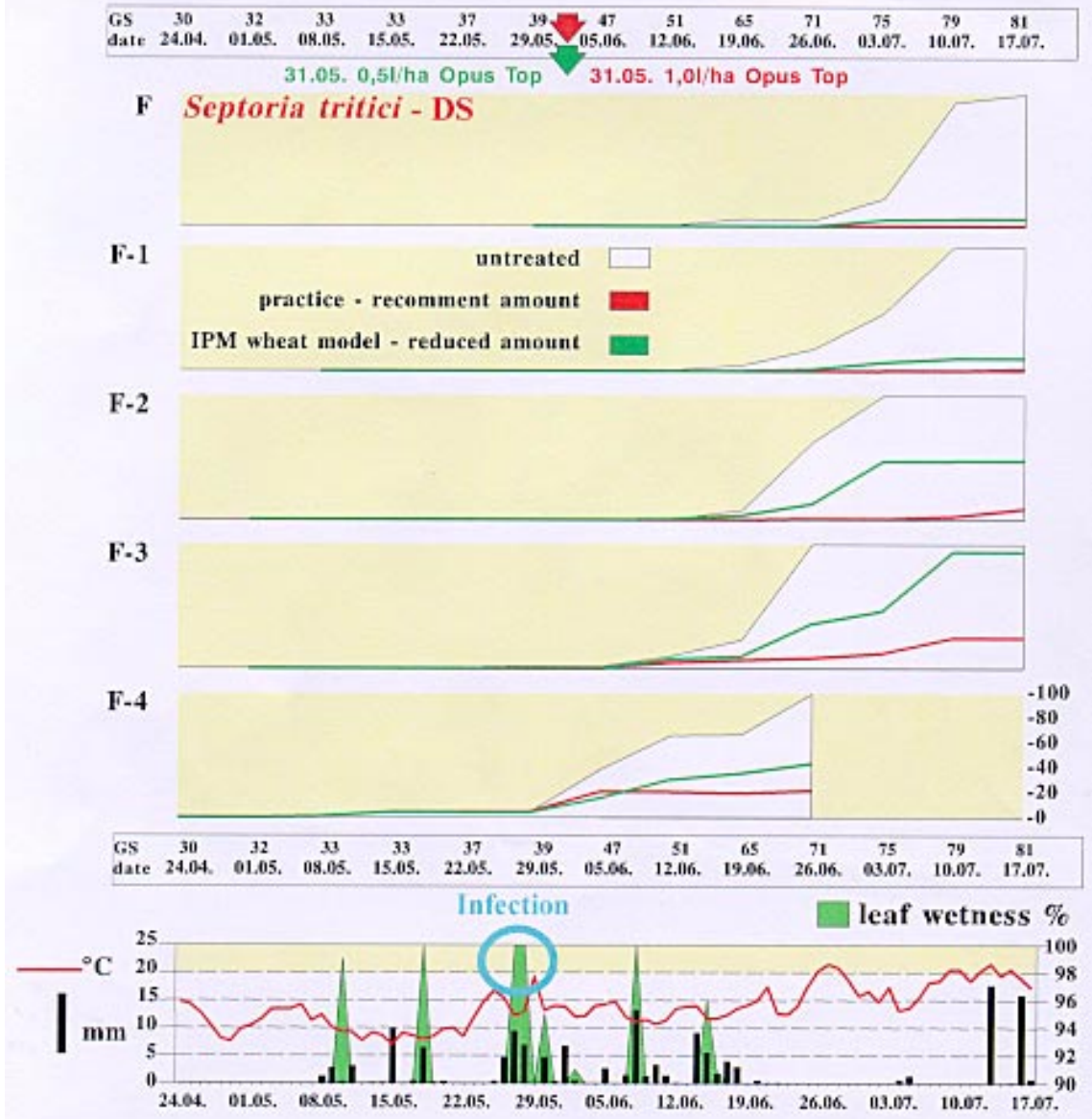

Fig. 14. Control of Septoria tritici oriented according to the criteria of the infection conditions in the case of reduced (green curve) (IPM wheat model) and full-rate fungicide applications (red curve) (Opus Top = epoxiconazole plus fenpropimorph) compared with the untreated control (white field) on leaf positions F-4 (= fifth leaf from top) to F (= flag leaf). Sampling period GS 30 to GS 81 (24 April to 17 July). Site Eesch, variety Ritmo, 1995 . DS = disease severity. Weather data: temperature $\left({ }^{\circ} \mathrm{C}\right)$, precipitation (mm), and leaf wetness (\%). 


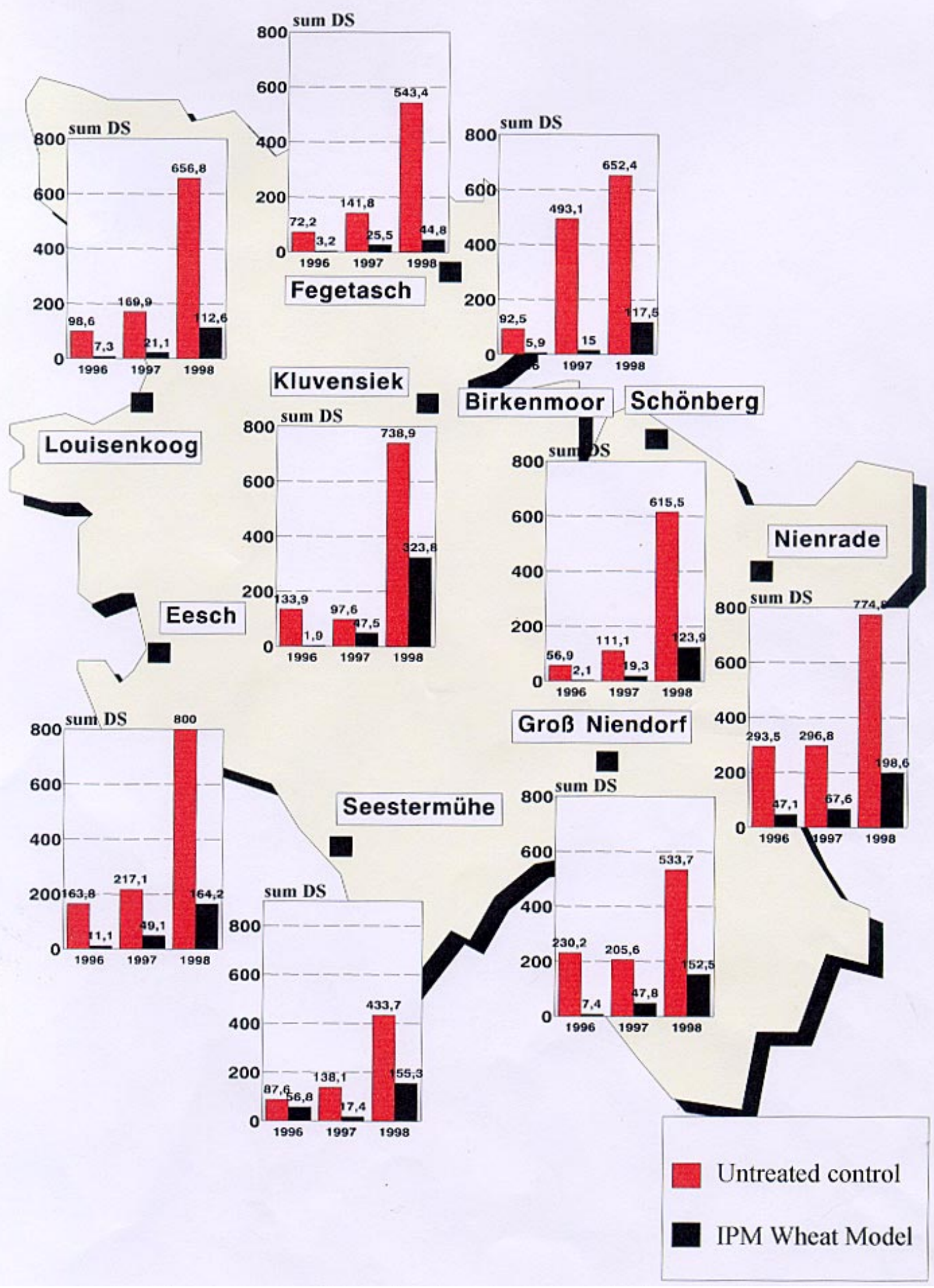

Fig. 15. Regional disease severity of Septoria tritici according to the IPM wheat model (black column) compared with the untreated control (red column). Disease severity at growth stage GS 75 is represented through the pycnidia count per plant totaled over the leaf positions F-6 (= seventh leaf from top) to F (= flag leaf), 1996 to 1998. 


\section{Acknowledgments}

We thank the German Research Society (Deutsche Forschungsgemeinschaft) and the Schleswig-Holstein Ministry for Rural Areas, Agriculture, Nutrition and Tourism for financial support.

\section{Literature Cited}

1. Büschbell, T. 1990. Phytopathologische Grundlagen des integrierten Pflanzenschutzes gegen Pilzkrankheiten in Weizenanbausystemen. Dissertation Technische Universität München-Weihenstephan.

2. Food and Agriculture Organization of The United Nations. 1999. Statistical Databases, FAOSTAT AGRICULTURE DATA, Agricultural Production, Crops Primary. On-line publication.

3. Gheorghies, C. 1974. Contribution to the knowledge of the biology of Septoria tritici Rob. et Desm. 1. Germination of pycnidiospores. An. Inst. Cercet. Prot. Plant. 10:63-70.

4. Gough, F. J., and Lee, T. S. 1985. Moisture effects on the discharge and survival of conidia of Septoria tritici. Phytopathology 75:180-182.

5. Hilu, H. M., and Bever, W. M. 1957. Inoculation, oversummering and suscept and pathogen relationship of Septoria tritici on Triticum diseases. Phytopathology 47:474-480.

6. Holmes, S. J. J., and Colhoun, J. 1974. Infection of wheat by Septoria nodorum and Septoria tritici in relation to plant age, air temperature and relative humidity. Trans. $\mathrm{Br}$. Mycol. Soc. 63:329-338.

7. Käsbohrer, M. 1986. Epidemiologie und Ertragsrelevanz von Fuß-, Blatt- und Ährenkrankheiten in verschiedenen Weizenanbausystemen. Dissertation Technische Uni- versität München-Weihenstephan.

8. Käsbohrer, M., Hoffmann, G. M., and Fischbeck, G. 1988. Die Befallshäufigkeit als Entscheidungshilfe für die Bekämpfung des Echten Mehltaus (Erysiphe graminis f. sp. tritici) an Weizen. Z. Pflanzenkrankh. Pflanzenschutz 95:1-15.

9. Käsbohrer, M., Hoffmann, G. M., and Fischbeck, G. 1988. Zur Entwicklung der Halmbruchkrankheit (Erreger: Pseudocercosporella herpotrichoides) in vergleichbaren Weizenanbausystemen. Z. Pflanzenkrankh. Pflanzenschutz 95:611-629.

10. Klink, H. 1997. Geoepidemiologische Erhebungen von Weizenpathogenen in SchleswigHolstein unter Anwendung und Entwicklung des Integrierten Pflanzenschutzsystems (IPS Modell Weizen) für einen minimierten, bedarfsgerechten Fungizideinsatz (1993-1996). Dissertation Universität Kiel, Fakultät Agrarund Ernährungswissenschaften.

11. Mauler-Machnik, A., and Naß, P. 1990. Einfache Methode zur Frühdiagnose von Pseudocercosporella herpotrichoides mit dem Bayer Getreide-Diagnose-System nach Verreet/ Hoffmann. Gesunde Pflanz. 42. Pages 130-132.

12. Schöfl, U. 1995. Evaluation of decision systems to control foliar diseases on wheat in the UK, with additional specific studies on Septoria tritici. Dissertation Technische Universität München-Weihenstephan.

13. Schöfl, U., Morris, D. B., and Verreet, J. A. 1994. The development of an integrated decision model based on disease threshold to control. Pages 671-678 in: Septoria tritici on winter wheat. Brighton Crop. Prot. Conf. Pests Dis. Vol. 2.

14. Shaw, M. W. 1990. Effects of temperature, leaf wetness and cultivar on the latent period of Mycosphaerella graminicola on winter wheat. Plant Pathol. 39:255-268.

15. Shaw, M. W., and Royle, D. J. 1987. Spatial distributions of Septoria nodorum and Septoria tritici within crops of winter wheat. Plant Pathol. 36:84-94

16. Shipton, W. A., Boyd, W. R. J., Rosielle, A. A., and Shearer, B. J. 1971. The common Septoria diseases of wheat. Bot. Rev. 37:231-262.

17. Verreet, J. A. 1992. Angewandte Grundlagen des Integrierten PflanzenSchutzes in Weizenanbausystemen - IPS Weizenmodell Bayern. Habilitationsschrift, Technische Universität München.

18. Verreet, J. A. 1995. Principles of integrated pest management - The IPM Wheat Model. Pflanzenschutz-Nachr. Bayer 48(66). Pages 0307.

19. Verreet, J. A., and Hoffmann, G. M. 1990. A biologically oriented threshold decision model for control of epidemics of Septoria nodorum in wheat. Plant Dis. 74:731-738.

20. Verreet, J. A., and Hoffmann, G. M. 1990. Threshold based control of wheat diseases using the Bayer cereal diagnosis system after Verreet/Hoffmann. Pages 745-750 in: Proc. Brighton Crop Prot. Conf. 3.

21. Wolf, P. F. J. 1991. Biologie, Epidemiologie, Schadrelevanz, Konzeption für eine integrierte Bekämpfung von Drechslera tritici-repentis (Died.) Shoem., (Perfektstadium Pyrenophora tritici-repentis (Died.) Drechs.) dem Erreger einer Blattfleckenkrankheit an Weizen. Dissertation Technische Universität München-Weihenstephan.

22. Wolf, P. F. J., and Hoffmann, G. M. 1994 Epidemiologisch begründetes Entscheidungsschema für eine integrierte Bekämpfung von Drechslera tritici-repentis (Died.) Shoem. (Telemorph Pyrenophora tritici-repentis (Died.) Drechs. Gesunde Pflanz. 46:164-173.

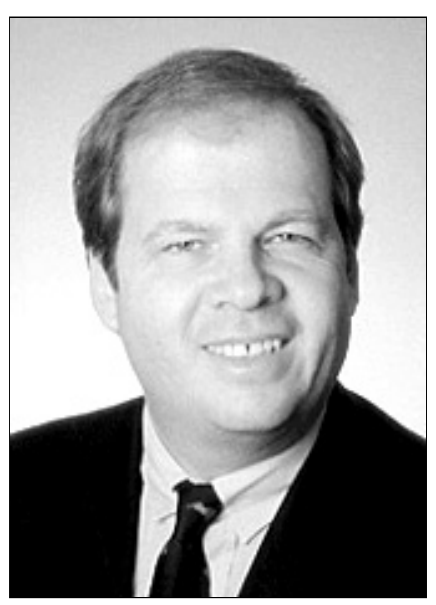

J. A. Verreet

Dr. Verreet is head of the Department of Phytopathology at the University of Kiel. He obtained his M.S. degree from the University of Bonn, his Ph.D. and habilitation degrees from the Technical University of Munich. His studies deal with mycological problems of several crops (e.g., rape, sugar beet, cereals). His current interests center on using epidemiology as a basis for control measures.

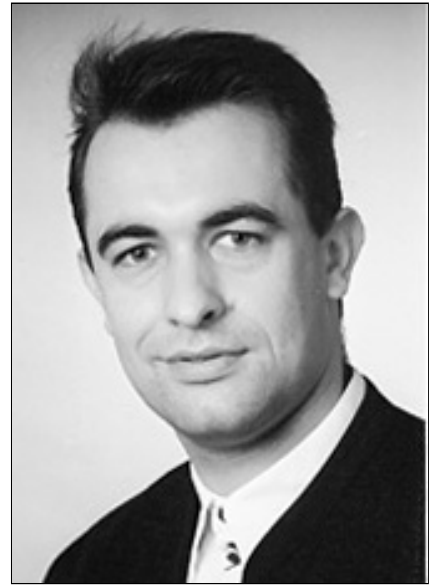

H. Klink

Dr. Klink, assistant in the Department of Plant Pathology at the University of Kiel, obtained his M.S. and Ph.D. degrees from the University of Kiel. $\mathrm{He}$ specializes in fungal diseases of cereals, with emphasis on analytical work on epidemiological principles, fungicide activities, and modeling wheat crop systems.

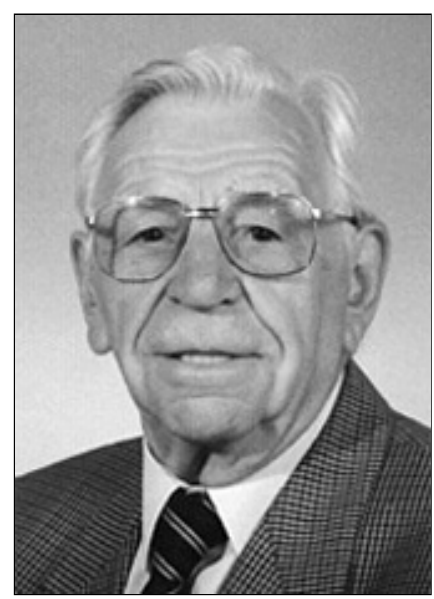

G. M. Hoffmann

Dr. Hoffmann (retired) was the head of the Department of Phytopathology of the Technical University of Munich. He obtained his M.S. and Ph.D. degrees from the University of Halle. He invented the IPM wheat, barley, sugar beet, and potato models, and had a considerable influence on the direction of the targeted scientific and applied research to develop and promote the introduction of the IPM models into practical agriculture. 